\title{
Balkanologie
}

Balkanologie Revue d'études pluridisciplinaires

Vol. VI, $n^{\circ}$ 1-2 | 2002

Volume VI Numéro 1-2

\section{Ambiguous partisanships}

Philhellenism, turkophilia and balkanology in 19th century Britain

Des prises de position ambiguës. Philhellénisme, turcophilie et balkanologie dans

l'Angleterre du XIX ${ }^{e}$ siècle

\section{Margarita Miliori}

\section{(2) OpenEdition}

Journals

Electronic version

URL: http://journals.openedition.org/balkanologie/449

DOI: 10.4000/balkanologie.449

ISSN: 1965-0582

\section{Publisher}

Association française d'études sur les Balkans (Afebalk)

\section{Printed version}

Date of publication: 1 December 2002

Number of pages: 127-153

ISSN: 1279-7952

\section{Electronic reference}

Margarita Miliori, «Ambiguous partisanships », Balkanologie [Online], Vol. VI, n 1-2 | 2002, Online since 19 May 2008, connection on 17 December 2020. URL : http://journals.openedition.org/balkanologie/ 449 ; DOI : https://doi.org/10.4000/balkanologie.449 


\section{AMBIGUOUS PARTISANSHIPS ; PHILHELLENISM, TURKOPHILIA AND BALKANOLOGY IN XIXth CENTURY BRITAIN}

Margarita Miliori*

\section{INTRODUCTION}

"Philhellenism" and "Turkophilia" connote an outsider's sympathy for Greeks and Turks respectively. "Balkanology", on the other hand, does not connote a similar kind of partisanship for a "foreign" national community, but rather an over-arching discourse constituting the Balkans as an internalized European Orient ${ }^{1}$. And yet, a number of more particular, nation-oriented discourses have historically grown under the wider "Balkan" umbrella. In this article I argue that comparing these discourses with earlier and contemporary discourse on "the Greeks" and "the Turks" significantly illuminates the history of Western perceptions of the Ottoman/Balkan area. In particular, it can help us understand how this history is related to the evolution of notions of nationality in nineteenth-century Western Europe, as well as the ideological ambiguities that emerged when these were applied to the societies of a region whose relationship to the "West" was considered to be in flux.

\section{The British Context}

In nineteenth-century Britain the "philhellenes" were those who supported Greek nationalist and/or hegemonic aspirations in South-East Europe, and the "Turkophiles" were those who supported the preservation of the Ottoman Empire and believed in its capacity to reform or to "regenerate" itself. On a first, superficial level, these partisan sympathies appeared to be mutually exclusive. However, a significant degree of ideological continuity underlay early

\footnotetext{
* Visiting Assistant Professor in History, Brown University, Rhode Island.

1 Todorova (Maria), Imagining the Balkans, Oxford, 1997; Goldsworthy (Vesna), Inventing Ruritania ; The Imperialism of the Imagination, Yale, 1998; Allcock (John), Young (Antonia), eds, Black Lambs and Grey Falcons. Women Travelers in the Balkans, Bradford, 1991.
} 
nineteenth-century British philhellenism and mid-nineteenth-century British Turkophilia. They both represented secular, commercially minded and politically liberal perspectives on the Eastern Question; as I will argue here, they should, in fact, be viewed as alternative articulations of the notion of a civilizing mission of Western Europe (with Britain at its head) towards the Ottoman "East".

The ways in which notions of Greek nationhood on the one hand and of Ottoman "nationalities" on the other entered into this picture between the 1820 s and the 1860 s is one of the most intriguing parameters of the whole issue. The middle decades of the nineteenth-century were a formative period for the articulation of modern notions of nationality in Britain, and the ways in which the issue was broached by philhellenes and Turkophiles may provide us with useful insights concerning the interdependence between concepts such as "patriotism" and "nationality" and wider world-views concerning civilization, progress and their political and historical geography.

What is particularly clear in this respect, however, is that from the middle of the nineteenth-century onwards the over-all image of the Ottoman and post-Ottoman "East" became a much more complex one, due to the growth of British sympathies for the Slav nations of the Ottoman Empire. Were these sympathies, especially for the Serbs and the Bulgarians, a mere amplification of earlier "philhellenism" ? Or were they a novel phenomenon, rising, at least in part, from a renunciation of an older, "philhellenic" frame of mind ?

In the last part of this article I will examine these questions and discuss, more generally, certain continuities in British attitudes towards the Ottoman and post-Ottoman societies of the Balkans that cut across particular national partisanships. But I will start by defining "philhellenism", and exploring its ideological connotations in Britain at the time of the Greek Revolution, in the 182os.

\section{SETTING THE STAGE FOR THE « MODERNS 》 : BRITISH PHILHELLENISM IN THE 1820S}

\section{Hellenism, Philhellenism and Nationalism in Britain of the $1820 \mathrm{~s}$}

According to Olga Augustinos, who succinctly summarizes the most common scholarly definition of the term, philhellenism is " a vision of a reborn and liberated Greece coming closer to the West by virtue of its Hellenic heritage ", a vision that was born out of the marriage of the anti-authoritarian political philosophy of the Enlightenment with a long-standing literary tradition of Hellenic travel ${ }^{2}$.

\footnotetext{
2 Augustinos (Olga), French Odysseys; Greece in French Travel Literature from the Renaissance to the Romatic Era, Baltimore / London, 1994, p. xii.
} 
Such definitions have frequently encouraged scholars to subsume the history of Western perceptions of Greek modernity under the history of pre-182os travel literature on Greece and, consequently, to underestimate the importance of the Greek Revolution of the 1820 s as the defining moment in the institution of a "national" Greece in Western discourse and imagination. In order to redress the balance, I propose here that both Hellenic travel and Hellenism in general ${ }^{3}$ have been overestimated as determining factors in the construction of images of a modern and national Greece in the early nineteenth century. A more qualified assessment of the specific intellectual and ideological contexts within which visions of Greek modernity arose in the 1820 s would rightly re-direct our perspective of Western discourse on Greece, from its eighteenth century "pre-history", towards nineteenth-century phenomena, such as the development of the Eastern Question debate and the rise of European nationalist ideologies.

In early nineteenth-century Britain, definitions of nationality were hard to separate from the notion of an established political community. Notions of nationhood were influenced by an indigenous "patriotic" tradition that had developed in the context of an early appropriation of the rhetoric of the nation in political discourse. This rhetoric had also been colored from the late eighteenth century onwards by Burkean notions of a continuous national (cum political) development, unfolding in an organic fashion though historical time4. In addition, the 1820 s was a period during which British post-Napoleonic pride for their own political role in Europe reached its height. As the contemporary popularity of Canning's "open diplomacy" indicates, Britain's ability to master historical and political circumstance in the international arena acquired growing importance for British national self-perceptions from the 1820 s onwards.

Furthermore, in early nineteenth-century Britain, Hellenist discourse was already pervasive as a discourse on literary and aesthetic values, and was already deeply implicated with issues of social differentiation, taste and class. Ancient Greek politics, however, were still not expurgated from negative associations with revolutionary France, neither were they elevated to their mid-nineteenth

3 I use the term as in Turner (Frank), The Greek Heritage in Victorian Britain, Yale, 1981 ; Clarke (G.W.), Eade (J.C.), eds, Rediscovering Hellenism : The Hellenic Inheritance and the English Imagination, Cambridge, 1989 ; Stray (Christopher), Classics Transformed : Schools, Universities and Society in England, Oxford, 1998. That is, to connote the appropriation of the ancient Greek literary, philosophical and aesthetic heritage into the intellectual and institutional framework of modern western societies, together with the diverse strands of interpretative exegesis that it entailed. The fact that other scholars have used the term " philhellenism " to describe more or less the same thing (most notably, Marchand (Suzanne L.), Down from Olympus ; Archaeology and Philhellenism in Germany, 1750-1970, Princeton, 1996), further illustrates my point about the scholarly conflation of the discourses on ancient and modern Greece.

4 Breuilly (John), Nationalism and the State, $2^{\text {nd }}$ edition, Manchester, 1993, pp. 84-88 ; Dinwiddy (John), "England " in Dann (Otto) / Dinwiddy (John), eds, Nationalism in the Age of the French Revolution, London, 1988, pp. 53-70 ; and Colley (Linda), Britons : Forging the Nation 1707-1837, London, 1992, passim. 
century liberal pedestal, rightly associated with George Grote and John Stuart Mill5. They could not, therefore, provide a positive precedent, or a model of government, for a "re-constituted" Greek national (cum political) body.

The standard authority on Greek history at the time of the Greek Revolution was William Mitford's History of Greece ${ }^{6}$. Written during the Napoleonic Wars, this was conceived as a scholarly exposition of the "irrelevant " and " unnatural " character of ancient Greek (and revolutionary French) politics in comparison to modern European liberty, of which English liberty was presented as the prime and the guiding example7. Although Mitford's History came under the fire of serious criticism in the $1820 \mathrm{~s}^{8}$, this criticism was not reflected in philhellenic texts. Rather, the popularity of Mitford's views amongst the active supporters of the "Greek cause" 9 indicates the centrality of self-congratulatory British discourse for the development of the philhellenic phenomenon. The fact that this self-congratulatory discourse was also interwoven with Hellenism (which may be understood, in this context, as an evolving exegesis of ancient Greek historical experience) indicates that the relationship between "Hellenism" and "philhellenism" was highly mediated, and, therefore, of a much less self-evident character than it is frequently assumed ${ }^{10}$.

Given this context, the Greek Revolution, while providing an opportunity to "export" British political "expertise" in the European arena, represented also an all-important test case for ascertaining the credentials of modern Greek

5 Grote (George), A History of Greece from the Earliest Period to the Close of the Generation Contemporary with Alexander the Great, 12 vols, London, 1846-1856 ; Mill (John Stuart), Dissertations and Discussions , Political, Philosophical and Historical, 4 vols, London 1859-1875, especially " Civilization " (1, pp. 160-205), " Early Grecian History and Legend " (2, pp. 283-334) and Grote (George) " History of Greece ", Edinburgh Review, 98, October 1853, pp. 425-447.

6 Mitford (William), History of Greece, 5 vols, London, 1784-1818.

7 For more, see Miliori (Margarita), The Greek Nation in British Eyes 1821-1864; Aspects of a British Discourse on Nationality, Politics, History and Europe, unpublished Ph.D. thesis, Oxford University, 1998, pp. 19-29.

8 See Macaulay (T. B.), " On Mitford's History " [1824], Complete Works of T.B. Macaulay, 12 vols, London, 1898 (11, pp. 365-393), Grote (George), "Institutions of Ancient Greece ", Westminster Review, 5, April 1826, pp. 269-331.

9 Napier (Charles), War in Greece, London, 1821, pp. 5-6 : " Greece has never been well governed [...]. First she was divided into small states, and the least approach to any thing like good government among them the very smallness of these states, this very division of Greece, was a political sin against the people " ; Sheridan (Charles B.), Thoughts on the Greek Revolution, London 1822, p. 101, note 31 : "The French Revolution is the only parallel to the wild and guilty career of all the Greek Republics ; but the one was the paroxysm of a transient fever, the other a constitutional disease " ; Gordon (Thomas), History of the Greek Revolution, 2 vols, Edinburgh / London, 1832, (1, p. 2 : [Greek history after the Persian Wars was] " a deplorable succession of political crimes, domestic turmoil, discord, and hostility ").

10 The mental image of the British and the Greeks occupying antithetical positions upon a common scale of European political virtue (an image upon which the notion of philhellenic political tutelage was based), becomes even clearer when we take into consideration that the post-classical history of the 
"nationality". It was partly for this reason that British philhellenic experience during the Greek War of Independence, distilled into the historical, political and journalistic accounts of the philhellenes of the $1820 \mathrm{~s}$, and acquiring its full symbolic potential with Byron's death in Messolongi in 1824, became the cornerstone of later British perceptions of Greece ${ }^{11}$.

Furthermore, British philhellenic involvement with Greece in the 1820 s represented a politicized investment on the modern Greek future ; an investment that was considered relevant both to contemporary European politics, and to the future opening of the Ottoman world to the "West". The organizing center of philhellenic activity was the Greek Committee in London, led by a number of liberal and radical MPs. The secretary of the Committee was John Bowring, a liberal with strong interests in European politics and in national "awakenings" across Europe (including the Balkan peninsula) ${ }^{12}$, who was also, at the time, the editor of the newly founded Westminster Review, the mouthpiece of the "Benthamite" radicals.

Moreover, both the practical projects of the Committee and its mishaps, especially those surrounding the launch and the mismanagement of the Greek loans of 1824-1825, led to a high degree of political controversy both in Britain and in Greece ${ }^{13}$. And last but not least, although the Greek Committee tried to gain a wider audience in favor of the Greeks, the republican and freetrade ideals of its most active publicists strongly colored the rhetoric and the ideological character of the movement as a whole ${ }^{14}$.

Philhellenism was, thus, both "political" and "ideological"; yet the extent to which it may be viewed as synonymous with support for Greek "nationalism"

Greeks (and most notably Byzantium) was subsumed at this time under Gibbon's interpretation of the decline and fall of Rome.

11 Byron's elevation to the symbolic figurehead of British philhellenism should be seen as mediated by the accounts of his collaborators in Greece. See Miliori (Margarita), op.cit., pp. 109-124.

12 By the early 1820 s Bowring had already edited and/or translated an impressive number of folk-song collections from all corners of Europe, including the following : Ancient Poetry and Romances of Spain (1824), Batavian Anthology (1824), Servian Popular Poetry (1827), Cheskian Anthology (1832), Poetry of the Magyars (1830), Speciments of the Polish Poets (1827), Speciments of the Russian Poets (1821-1823). His Servian Poetry, dedicated to the Serb linguist and collector of folksongs Vuk Karadzici, is one of the first specimens of British interest in the Slavs of the Balkans. See Wilson (Duncan), The Life and Times of Vuk Stefanović Karadžić 1787-1864 ; Literacy, Literature, and National Independence in Serbia, Oxford, 1970, pp. 203-207.

13 Thomas (William), The Philosophic Radicals; Nine Studies in Theory and Practice 1817-1841, Oxford, 1979, pp. 163-167; Rosen (Frederick), Bentham, Byron and Greece : Constitutionalism, Nationalism and Early Liberal Political Thought, Oxford, 1992, passim.

14 See mainly Blaquiere (Edward), Repart on the Present State of the Greek Confederation, London, 1823 ; The Greek Revolution : Its Origins and Progress, London, 1824 ; Narrative of a Second Visit to Greece, London, 1825 ; Stanhope (Leicester), Greece in 1823-1824, London, 1824, and second edition 1828, under the title Greece in 1823-1825; Sherddan (Charles Brinsley). Thoughts on the Greek Revolution, London, 1822 ; Fauriel (C.), ed., The Songs of Greece, London, 1825. 
remains a complex and open question, involving a subtle re-assessment of both Greek revolutionary politics and the ideological backgrounds from which different British philhellenes approached them. In turn, this would be likely to bring forth one's own prejudices concerning the relative importance of different values within the spectrum of ideas related to national self-determination. This temptation is difficult to resist in this instance, because here we are faced with an historical moment when such concepts were still in the making ${ }^{15}$.

What is certain, however, is that while the Greek War of Independence was openly viewed as a "national cause" at the time, the exact meaning of Greek national self-determination remained a contested issue throughout the revolutionary decade, both in Greece itself, and in the writings of the British philhellenes. Issues that may be considered central to any kind of nationalist theory were posed by philhellenic experience and were frequently discussed in philhellenic writings. Such issues were, for example, the relationship between "local" and "national" patriotism ${ }^{16}$; whether the establishment of a "foreign" monarchy in conditions of intense civil strife would compromise Greek self-determination ${ }^{17}$; and the respective roles that the various classes of Greeks would, or should play in the new body-politic ${ }^{18}$.

Yet none of these questions was adequately answered by (or for) the early philhellenes by the establishment of the Hellenic Kingdom under the Bavarian dynasty of Otto in 1833 . Most philhellenes of the 1820 s were critical of the monarchical solution to the Greek political problem, while the precise meaning of a "national" government in the Greek context remained an open question,

15 Frederick Rosen, aiming to clarify the relationship between the philhellenic movement and early nineteenth-century British liberalism, has argued that one group of liberal philhellenes were " nationalists n, in the sense that the Mediterranean nationalist movements of the early nineteenth century were central to their ideological formation, while another subscribed to an " authoritarian counter-current " of British liberal thought, stemming from British rule in India (Rosen (Frederick), op. cit., pp. 126-158). His analysis implies that the ultimate marker of a " nationalist " philhellene was prioritizing the creation of a unitary nation-state at all costs. It may be argued, however, that issues such as the representative qualities (or defects) of the projected political organization of Greece, the " popularity " of its projected government and the foreign or indigenous provenance of its prospective rulers, could provide equally valid " nationalist " markers of philhellenic perspectives at the time.

16 This theme was very common. By the end of the revolutionary decade " local patriotism " had become a stereotypical Greek vice (see Gordon (Thornas), op. cit., 1, p. 313) ; or virtue (see mainly Finlay (George), The Hellenic Kingdom and the Greek Nation, London, 1836, pp. 33-34).

17 Sheridan (Charles Brinsley), Songs of Greece (op. cit.), pp. lvii-lviii.

18 Most philhellenes hoped that the leaders of the modem Greek body politic would turn out to be the commercially minded and western-educated elites. Leake (W. M.), Historical Outline of the Greek Revolution, London, 1825, Pp. 61-62 ; Napier (Charles), Greece in 1824, London, 1824, Pp. 11-12. A considerable number, however, considered the peasantry as the "national class " per excellence, and admired the " indigenous " leaders of the Revolution. Stanhope (Leicester), Greece in 1823-1825 (op. cit.), pp. 359-361, 411-416, 443 (footnote) and the three accounts included in A Picture of Greece in 1825 : As exhibited in the Personal Narratives of James Emerson, Count Pecchio and W.H. Humphreys, 2 vols, London, 1826, especially Humphreys (2, pp. 198-338). 
even in philhellenic circles, long after the War had ended. For example, George Finlay's strictures about the "anti-national" centralizing policies of the Bavarians, first publicized in 1836 in his Hellenic Kingdom and the Greek Nation, would gradually acquire a serious hearing amongst the British public, especially in the 1850 s and 1860 . However, even in his case, to adopt a "national" policy in Greece signified primarily to adapt the administrative system of the country to what he considered to be the "truly Greek" traditions of local selfgovernment. It certainly did not entail embracing full-heartedly the idea that government by one's co-nationals was a political good in itself ${ }^{9}$.

\section{The Greeks, the British and the Eastern Duestion}

Leaving aside for the moment the narrowly political aspects of British philhellenic ideology, and turning to its supra-national aspects as a "Western" crusade, we should again challenge the prevalent assumption that philhellenic expectations of a West-oriented Greek future stemmed "naturally" from an acknowledgement of a "national" connection between the ancient and the modern Greeks.

It is true that in the philhellenic writings of the 1820 s the presumed "Western" or "European" qualities of the modern Greeks (namely their "talent" for education and for commerce) were often praised, and this was usually coupled with allusions to a "revival" of the ancient Greek spirit amongst them. The first part of such arguments, however, was not a mere projection of the second, since the usual examples of Greek "industry" were not Athens or Corinth, but rather the successes of the modern Greek communities in the Habsburg Empire and in the cities of the West ${ }^{20}$. Frequent allusions were also made to the naval exploits of the Greek islanders, who, in their relative autonomy from the central Ottoman authorities, ideally represented, in philhellenic eyes, the anticipated commercial dynamism of liberated Greece ${ }^{21}$.

On the whole, the argument concerning the inevitable character of an ongoing struggle between expanding European progress and defensive Ottoman stagnancy - the "Turks" being frequently depicted as " a nation utterly resisting the approaches of that brilliant and productive civilization which absolutely

19 Finlay participated to the Greek War of Independence between 1823 and 1827 , and by 1830 had established himself in the country as an " agricultural capitalist ". Such early plans failing, he later became the most influential "Greek "expert in the eyes of British public opinion, sending to London and Edirburgh various writings on Greece throughout his life (d. 1876). His best known work is Finlay (George), A History of Greece from its Conquest by the Romans to the Present Time B.C. 147 to A.D. 1864 [Edinburgh, 1844-1861], new edition, edited by Tozer (H. F.), 7 vols, Oxford, 1877.

20 Brougham (Henry) "Sir William Gell's Greece ", Edinburgh Review, 38, May 1823, p. 321 ; Sheridan (Charles Brinsley), Thoughts on the Greek Revolution (op. cit.), pp. 84-85, note 51.

${ }^{21}$ Brougham (Henry), op.cit., p. 325 ; Hughes (Thomas), An Address to the People of England in the Cause of the Greeks, Occasioned by the Late In human Massacres in the Isle of Chios, London, 1822, pp. 27-28. 
surrounds and urges itself on it in every form ${ }^{22}$ - was much more sharply drawn in philhellenic rhetoric than the argument about the national revival of the ancient Greeks. Rather than constituting, by itself, the underlying motive of philhellenic activism, the "integral" Europeaness of the Greeks was only one of the constituent elements of a dynamic rhetorical strategy, through which notions of modern Europeaness, modern Britishness and modern Greekness were formulated anew and in relation to each other.

As a result of this strategy, side by side with images of Britannia tutoring younger nations in political virtue, visions of an emerging free-trade world, prospering under the enlightened leadership of British commerce, were also projected upon the wider area of the Eastern Mediterranean. Such visions were more prominent in the writings of the radical spokesmen of the Committee, like its secretary John Bowring, its agents in Greece Leicester Stanhope and Edward Blaquiere, and the head of its literary sub-Committee, Charles Sheridan; but they were also put forward by philhellenes who did not belong to this circle, such as the influential traveler and topographer William Martin Leake, or the conservative Cambridge clergyman Thomas Hughes ${ }^{23}$.

It would seem that these visions concerned very little the opponents of the Greeks, the Ottoman Turks, or the other nations of the Ottoman area. However, the faith of the philhellenes that futurity was on their side indicated that, left to its own devices, the Ottoman Empire was doomed. This belief rendered British official support for the Ottomans against the Greeks not only immoral, but also futile, in their eyes, so many argued that support for Greek Independence was the only viable means to counteract Russian expansionism southwards ${ }^{24}$. Given this wider strategic context, specific visions of a complementary future between "the Turks" and "the Greeks" were also formed. For example, in 1822 Charles Sheridan imagined a future harmony between the two peoples in the following terms :

As neighbours they will suit, from the opposition of their tastes and interests; the Turks no more clashing with the Greek ventures to Marseilles, than the Greeks with the Turkish pilgrimages to Mecca. The Turks will avail themselves of industrious neigh-

\footnotetext{
22 Quoted from Croly (George), " Greece ", Blackwood's Magazine, 20, October 1826, p. 547. Croly also
} wrote a poem on the Serbian Karadjordje around this time. See Goldsworthy (Vesna), op. cit., pp. 24-25.

23 Hughes (Thomas), op. cit., pp. 27-28: " The whole of Greece emancipated from barbarian oppression, would become as Hydra, Spezie, and Ipsara : like South America, she would open a capacious mart of European produce : England would be the first country to enjoy the advantages of this commerce n.

24 Napier (Charles), Greece in 1824, London, 1824, passim ; Anon., "Greece and Russia ", Westminster Review, 1, April 1824, pp. 453-471. 
bours, and the Greeks of unenlightened customers ; and whatever change occurs must be for the advantage of the latter. Peace is necessary to educate Greece, and war is the one thing likely to revive the slumbering genius of Mahometanism 25 .

The impressive way in which Sheridan's bipolar image recasts the Greek ventures to Marseilles' as the essence of Greekness, while he presents commitment to Islam as the essence of "Turkishness", should not make us lose sight of the fact that what happens here is not a mere re-iteration of stereotypes about two "nations". While Sheridan writes about "Greeks" and "Turks", the traditional antithesis between Christian Europe and the Islamic East is almost imperceptibly rewritten into something distinctly modern ; it is recast as a relationship between industrious European capitalists and their passive "Eastern" markets, sharing an integrated and peaceful, but clearly unequal world.

\section{SHARING A DIVIDED WORLD : THE TURKS AND THE GREEKS IN BRITISH EYES, 1830-60}

\section{Turkophilia and Philhellenism}

The period between the institution of modern Greece in the early 1830 s and the Treaty of Paris (1856) was a period during which Palmerstonean liberalism and its concomitant doctrine of support for the Ottoman Empire prevailed in British politics.

Viewed from the vantage point of this era, the ideological legacies of early philhellenism appear diffused amongst various strands of British liberal thought on nationality, Europe, and the Ottoman Empire. On the one hand, this diffusion underlines the importance of the "philhellenic affair" of the 1820 s within the history of British liberalism. On the other, it shows how a number of liberal themes and ideas that had found a prominent vehicle of expression in philhellenism in the 1820 s were subsequently dissociated from commitment to the interests of Greece. To give only one example, in Shelley's philhellenic " Preface " to his poem Hellas (1821) we find an early and eloquent formulation of the theme of a common crusade of the liberal " peoples " of Europe against the united forces of the European autocrats ${ }^{26}$. This theme became very popular amongst British liberals in the 184 os and 1850 s. Yet, Greece, more frequently than not, was excluded from such mid-nineteenth century

25 Sheridan (Charles Brinsley), Thoughts on the Greek Revolution (op. cit.), p. 75.

26 Shelley (P.B.), " Preface to Hellas ", in Igpen (R), Peck (E.A.), eds., The Complete Works of Percy Bysshe Shelley, 10 vols, London / New York, 1965, iii : 8. 
liberal mental maps of Europe : Greek nationalism was considered problematic regarding "liberal Europe's" archenemy, autocratic Russia.

Ultimately, if we dismiss the notion of an a priori mutual exclusivity between sympathies for "Greeks" and "Turks", we will find that the clearer resonance of early philhellenism in mid-century Britain is to be found amongst liberally-minded mid-nineteenth-century Turkophiles. The "Eastern" perspectives of two influential publicists, Henry Austin Layard and David Urquhart provide cases in point ${ }^{27}$.

The prominent diplomat and "orientalist" Austin Henry Layard ${ }^{28}$ was a firm supporter of Ottoman reform and contributed to a number of pro-Ottoman articles to the conservative Quarterly Review during the Crimean War. A first indication of continuity with earlier philhellenism in these writings is the total absence of concern for the Empire's non-Christian subjects. Indeed, Layard viewed Ottoman reform as a means to promote the "progress " of the Christian populations of the Empire and to ensure their gradual ascendancy over the Turks, while the terms in which he understood this progress and the means he envisaged for attaining it were strongly reminiscent of the earlier philhellenic " mission ${ }^{29}$.

Thus, the "national progress" (sic) of the Christians ${ }^{30}$ was construed in distinctly secular and material terms, i.e. as an " increase in wealth and intel-

27 Their approaches should be seen against the background of a significantly wider, but more diluted wave of liberal Turkophilia, culminating at the time of the Crimean War. The main concerns of this strand of liberalism lay in Central and Eastern Europe (Poland, Hungary, Germany), where liberal and national causes were seen as threatened by Russian and Austrian absolutism. See Martin (Kingsley), The Triumph of Lord Palmerston: A Study of Public Opinion in England before the Crimean War, new edition, London, 1963 ; and Anderson (Olive), A Liberal State at War : English Politics and Economics during the Crimean War, London, 1967.

28 Layard gained his expertise on the East in 1842-51 as a protége of Stratford Canning in Istanbul, and as an excavator of Nineveh. He became under-secretary of foreign affairs for significant periods in the $1850 s$ and 1860 s, and served as a British minister in Madrid and Constantinople after 1866.

29 Layard (A. H.), "Turkey and Russia ", Quarterly Review, 94, December 1853, pp. 288-301 and Layard (A. H.), "The Peace and its Effects on the Condition of Turkey ", Quarterly Review, 98, March 1856, pp. 502583. Introducing an uncommon racial argument to the debate, Layard argued that this ascendancy was inevitable on the long nun, since the "Indogermanic races " were inherently superior to the "Tartar and Mongolic " ones.

30 There is no sense in Layard's writings that " national " terminology could, altematively, be applied either to "Turks " "Ottomans " or "Muslims ". This is typical of British discourse on the Eastern Question at the time of the Crimean War, even amongst ardent Turkophiles, who (with the exception of David Urquhart) rarely even mention Ottoman " patriotism " in any sense. This absence becomes even more conspicuous if British texts are compared with some specimens of French Turkophile literature of the 185os. For example, in his Preface to the History of Turkey, published during the Crimean War, Alphonse Lamartine clearly writes of the Turks as a " people $n_{\tau}$ describes their " heroism " and emphasizes the efforts of Abdul Mecid to " nationalize all the fragments of the nations that cover the soil of Turkey". Lamartine (Alphonse), History of Turkey, 3 vols, New York, 1855, p. 18. 
ligence " ; Layard believed that it would be attained through the opening of the Empire to European capitalist investment and through Western political influence and control exercised by able European consuls ${ }^{31}$; while, Protestant proselytizing would play only a complementary role in the process, fighting to counteract the obscurantism of the Greek Church ${ }^{32}$.

The stress Layard placed on European initiative regarding Ottoman reform distanced his perspective from that of David Urquhart, whose views we will examine shortly, but brought him very close to the secular, commercially minded and progressist mainstream of British philhellenic opinion of the 1820 s. The main difference between Turkophile liberals of Layard's sort and the philhellenes of the 1820 s was a difference concerning means, not ends : in the 1850 , Layard no longer viewed the Porte as the bulwark of traditional Ottoman intransigence. To him, it was primarily a central political organ for the dissemination of a policy dictated by Western diplomatic advice. The major impediment to progress amongst the Ottoman Christians was now considered to be Russian and Church influence, not the Porte 33 .

The ardent Turkophilia of David Urquhart, on the other hand, bore a much more integral relationship to philhellenism. After participating in the War of Independence on the side of the Greeks in 1827-1829, Urquhart had followed Stratford Canning to Istanbul as a diplomatic agent and spent there and in the Black Sea most of the 1830 s. During this time he turned to a committed Turkophile ${ }^{34}$, his partisanship nurturing from his extreme Russophobia, but also from a deep admiration for traditional Ottoman society.

Urquhart's best - known book, the Spirit of the East (1838)35, was unique amongst contemporary travel books on the Levant in its defense of Islam, which was presented as a species of Protestantism : as offering a fundamentally

31 Layard (A. H.) "The Peace and its Effects " (art. cit.), pp. 523, 533 .

32 For Layard's criticism of the Orthodox Church see "Turkey and Russia ", Quarterly Review, 94 , December 1853, pp. 280-281.

33 Interestingly, during the same period, the "veteran" philhellene George Finlay published an article in Blackwood's Magazine in which he welcomed the blockade of Piraeus by the allies as a means to "defend" the Greek people (presumably from themselves) ; while he also strongly condemned the historical role of the Orthodox Church in Greek history, "Otho and his Classic Kingdom ", Blackwood's Magazine, 76 , October 1854, pp. 403-421.

34 Urquhart launched his first propaganda campaign in 1835, but he is better known for his activity during the Crimean War, when his eccentric political doctrines and his intense Russophobia attracted a significant number of radical supporters amongst the urban populations of the West Midlands. This led to the creation of the "National League", a radical organization with particular success in 1854-1855.

35 Urquhart (David), The Spirit of the East. Illustrated in a Journal of Travels through Roumeli in an Eventful Period, 2 vols, London, 1838. The book went into a second edition in 1839 and was translated into German. 
egalitarian cultural, political and economic model, undermining privilege and opening the way for free-trade and progress ${ }^{36}$.

More traditionally, Urquhart also presented Islam as the underlying cohesive force of Ottoman society and culture, a view that was combined with stereotypical orientalist clichés, especially of a romantic kind (such as the antithesis between the integral and natural life "of the East" and the mechanical and alienated life in the West). And yet, viewed as a piece of orientalist literature, the Spirit of the East was quite idiosyncratic in that it clearly promoted domestic rather than exotic images of Ottoman society ; images that were described in great anthropological detail37. Such elements, combined with Urquhart's unusual focus on the local economic and administrative structures of the Empire, brought him closer, in my view, than any other British Turkophile of this era to presenting Ottoman society as a "national" society ${ }^{38}$.

Being sincere, and almost "national", Urquhart's "love for the Turks" in the mid-183os bore all the signs of a real "conversion" from his earlier philhellenism 39 . However, his slightly earlier book, Turkey and its Resources (London 1833) rather complicates the issue, as, here, Urquhart's already strong Turkophilia quite happily co-existed with still distinctive signs of philhellenism $4^{\circ}$.

The first major theme of this book were the commercial prospects of the Ottoman Empire, whereupon Urquhart envisioned complementary roles for the industrial West (with Britain in the leading role) and agricultural Turkey that would profit both sides. The second were the traditional " municipal institutions of Turkey ", which Urquhart presented as the safeguard of the moral virtues of both the Muslim and the Christian peasantry and as the main means towards Ottoman political salvation.

36 See ibid, (1, pp. viii-xxi). Also, Urquhart (David), " Character of Turkish Populations and Religions ", British and Foreign Quarterly Review, 2, January 1836, pp. 1-35.

37 See in particular Urquhart (David), op. cit., ch. 25 " The Life of the Harem " and ch. 26 " State of Women- Their Influence on Domestic Manners and National Character - Comparative Morality of the East and the West ", 2, pp. 226-265. The images drawn here, I would argue, provide a literary equivalent of mid-nineteenth century British orientalist painters like J.F. Lewis, rather than being reminiscent of the more well- known orientalist images of J.A.D Ingres and E. Delacroix, or, even, of the French "realist" Orientalists, of the Jean-Leon Gerome school. On pictorial Orientalism see the excellent survey by Benjamin (Roger), " The Oriental Mirage " in Benjamin (Roger), ed., Orientalism. Delacroix to Klee, New South Wales, 1997, pp. 5-30.

38 Some other idiosyncratic elements enhance this view. See for example Urquhart's hymn to the Ottoman flag, Urquhart (David), op. cit., 1, pp. 19-23.

39 As early as 1836 Urquhart argued that the best solution to the Greek political problem would be for Greece to revert to Ottoman rule. See Urquhart (David), " Russian Policy in Greece ", Foreign Quarterly Review, 16 , January 1836, pp. $381-383$.

40 Cf. Urquhart's philhellenic comments on Greece in Urquhart (David), Turkey and its Resources : Its Municipal Organization and Free Trade; the State and Prospects of English Commerce in the East, the New Administration of Greece, its Revenue and National Possessions, pp. 256-259. 
The book was instantly reviewed in the Westminster, where Urquhart's analysis was applied to Greece in order to denounce the recent establishment of a centralizing monarchy in the country. His reviewer implied that Urquhart, as a " veteran " philhellene, had discovered that Greek " local patriotism " was deeply averse to centralization, rendering the Greeks, in this limited sense, " republican " ${ }^{1}$. In the following decades, the same argument would be thoroughly applied to Greece by George Finlay, who rendered the " local institutions of Greece " the distinctive badge of his own philhellenism.

Indeed, throughout his life the "veteran" philhellene would insist on the primary value of a grass-roots type of patriotism, nurtured more by peasant traditions than by modern constitutional practice ; he would juxtapose the corruption of the modern Greek intellectual and political elites to the patriotic virtue of the Greek "people"; and, while living in Greece and retaining his selfidentification as a "philhellene" until the end of his life in the mid-1870s, he would refuse to identify philhellenism with the promotion of modern Greek nationalist ideology, becoming more and more critical, as time went by, of the Greek nationalists' emphasis on the role of the Orthodox Church in Greek national history ${ }^{2}$.

Thus, even more than the general terms of mid-nineteenth century "Turkophile" rhetoric, the strong similarities between Finlay's philhellenic and Urquhart's Turkophile perspectives reveal a substantial convergence between "expert" philhellenic and Turkophile analyses of the social and cultural world that "Turks" and "Greeks" still shared, while the parallel historical processes of transformation signaled as Greek "revival" and Ottoman "reform" had been set in motion.

\section{Redeploying the « Philhellenic Legacy 》: \\ The « new » philhellenes of the 1850s and 1860s.}

What I have argued so far seems to imply that liberal philhellenism of the 1820 s gradually dissolved into mainstream liberal Turkophilia of various strands. However, the over-all picture is more complex. For, ideological continuities between early philhellenism and later Turkophilia notwithstanding, during the Crimean War, and even more emphatically in the 1860 s, a number

\footnotetext{
${ }^{4}$ Anon, "Kingdom of Greece and the Ionian Islands ", Westminster Review, 19, Octber 1833, p. 505.

42 The development of Finlay's political argument on Greece, from his early support for constitutional government to his strict censure of the Greek political system in the 1850 s and 1860s, may be followed through his contributions to Blackwood's Magazine, that span the whole period. Also, we should note that he refused to use the term "Eastern Question " in his writings, preferring the term "Ottoman Question ", which fitted better with his interest on local government and land issues and with his aversion towards growing nationalist ideologies in the area. For his own comments on relevant terminology, see Finlay (George), "King Otho and his Classic Kingdom ", Blackwood's Magazine, 76, October 1854, p. 406, "The Euthanasia of the Ottoman Empire ", Blackwood's Magazine, 89, May 1861, p. 573.
} 
of scholars and publicists, belonging (more frequently than not) to what we may call "liberal/conservative" circles, entered the arena of public debate in order to defend an ostensible philhellenic tradition in British politics.

Aiming to tap into the symbolic capital of a "philhellenic legacy", within which traditional notions of English liberty merged with pride for British initiative and independence in European affairs, these "younger" philhellenes would gradually achieve a substantial re-working of earlier philhellenic schemas, providing the rhetorical and conceptual basis for the formulation of an anti-Ottoman, interventionist and "pro-nationalist" Eastern policy.

The writings of Henry Reeve, political commentator in the Times during the Crimean War and editor of the Edinburgh Review from July 1855, are a good example of the rhetoric of these "new" philhellenes. Writing critically on the prospects of Ottoman reform in $1854^{43}$, Reeve presented the contemporary dispute between Britain, France and Russia as a struggle that acquired moral legitimacy only when related to the underlying "contest" that was taking place between the Ottoman Porte and its Christian subjects. Reeve described this contest as " that of civilization and barbarism, of legislative rights and arbitrary power, of Christianity and Islamism, of the races of Europe and the races of Asia ", terms strongly reminiscent of the philhellenic rhetoric of the 1820 s 44 . He also proudly reminded his readers of the battle of Navarino, in order to emphasize the European " duty" to protect the Christians of the Empire ". These were considered now as " nationally " plural, including not only the Greeks but also the Slavs.

Other characteristic representatives of this younger generation were the historian E. A. Freeman 45 and the Scottish philologist J.S. Blackie ${ }^{46}$, who both entered the arena of public debate during the Crimean War as conscious "philhellenes", i.e. with the declared purpose to " defend " the Greeks against their detractors. Their philhellenism nurtured from their scholarly interests, but, at the same time, their militancy indicates that they viewed these scholarly interests as inseparable from a particular "partisan" commitment.

43 Reeve (Henry), " The Ottoman Empire ", Edinburgh Review, 99, January 1854, pp. 282-314.

44 Ibid., p. 298.

45 Freeman wrote numerous articles on modern Greece in the 1850 s and 1860 s. See, indicatively, Freeman (E. A.), "The Greek People and the Greek Kingdom ", Edinburgh Review, 103, April 1856, pp. 386422, "Medieval and Modern Greece ", The National Review, 18, January 1864, pp. 78-114.

46 John Stuart Blackie was born in Glasgow in 1809 and was educated in Scotland and in Germany. In 1850 he succeeded to the Greek Chair in Edinburgh. During the Crimean War he published a number of philhellenic articles and lectures, which show that he considered philhellenism a moral duty intrinsically connected with the intellectual integrity of the classical scholar, but also a "Scottish prophylactic " against the pedantry of English classicism. See Blackie (J. S.), On the Living Language of the Greeks, and its Utility to the Classical Scholar, Edinburgh 1853, "Language and Literature of Modern Greece ", North British Review, 20, November 1853, pp. 135-160, "Character, Condition and Prospects of the Greek People', Westminster Review, 62, October 1854, pp. 345-381. 
As compared with their counterparts of the generation of the 1820s, the philhellenes of the 1850 and 1860 s were more tolerant of the misgivings of Greek political life and more sympathetic towards Greek irredentism in the Balkans. They sought and developed contacts with contemporary Greek intellectuals living in Greece and studied their works, while they formed their notions of Greek nationality from various sources, including contemporary German scholarship in ethnology, linguistics and folklore.

They were also, on the whole, much more ready to acknowledge the principle of national self-government as a positive end in itself, rather than as a means towards the attainment of other political or social goals. Thus a "veteran" philhellene, William Martin Leake, could still argue in 1851 that it would have been better for Greece to have been made tributary to the Sultan in 1830 , on the grounds that, thus, «the Greeks would have received everything they wished for except the privilege of governing themselves, for which they were manifestly unfit " 47 . On the contrary, a "younger" one, E. A. Freeman, would argue a few years later that the fact that " Greece is again a nation [may] even counterbalance a certain amount of real misgovernment ", since, " men often prefer a bad government of their own to a good one forced on them by strangers $" 4^{8}$.

Apart from harboring more "modern" (and to us canonical) notions of nationality, these "new" philhellenes were also much less secular in their approach to the Eastern Question than their "veteran" counterparts. Their attitude towards the Ottoman Empire was strongly colored by anti-Islamic prejudice and by sympathies for the Greek Church. In particular, many amongst them were High-Anglicans, such as the theologians R. W. Church and J. M. Neale, or ex-High Anglicans, like the historian E.A. Freeman and the political leader who best expressed these new philhellenic concerns, W. E. Gladstone 49 .

In forming their identity as "philhellenes", this younger generation owed very little to the radical/republican or "Benthamite" frames of mind that had nurtured early philhellenic ideology. However, they owed a great deal to certain strands of scholarly philhellenism that had grown quietly between the 1830 s and the 1860 . Works on the history and the "present prospects" of the Greek Church, written by "veteran" philhellenes $5^{50}$, as well as George Finlay's History of Greece from its Conquest by the Romans to the Present Time, played

47 Leake (William Martin), Greece at the End of Twenty-Three Years Protection, London, 1851, p. 7.

$4^{8}$ Freeman (E. A.), "The Greek People and the Greek Kingdom ", Edinburgh, 102, April 1856, p. 419.

49 See Gladstone (W. E)'s early article on the Eastern Question, "The War and the Peace ", Gentleman's Magazine, new series, 1, August 1856, pp. 140-155.

so See Masson (Edward), An Apology for the Greek Church : Or, Hints on the Means of Promoting the Religious Improvement of the Greek Nation, London, 1844 ; Waddington (George), The Present Condition and Prospects of the Greek, or Oriental Church : With Some Letters Written from the Convent of the Strophades, London, 1829 (and a new, timely edition in 1854). 
an important role in the formation of the conceptual framework through which they approached both modern Greece and the Eastern Question.

Such "philhellenic" studies allowed this generation to move beyond an exclusive discourse on modern Greece, and to formulate conceptions of Europe that encompassed also its Southeastern part. This conceptual incorporation passed mainly through the secularization of the notion of Eastern Christianity, combined with the formulation of a theory about the role of religion as a means of national identification in the "East" 51 . It was also aided by a re-appreciation of the Byzantine and post-Byzantine world as a symmetrical, "Eastern" historical equivalent of a "Roman" and "post-Roman" Western Europe.

The prime example of this reading of Byzantine history is to be found in the numerous writings of E.A. Freeman, who openly acknowledged his debt to Finlay's scholarship, but moved distinctly beyond it ${ }^{22}$. Finlay described Byzantium as a coalition between a centralist and conservative " Roman " state and a despotic and corrupt Christian Church, whose joint impact upon the Greeks led to the suppression of the inherent progressive and democratic qualities of the nation. Freeman, on the other hand, described the "New Rome " as a civilizational matrix, within which the double (Greek and Roman) heritage of antiquity merged with Christianity, and from which a host of modern Slavic and European nations eventually sprung.

Thus with Freeman we encounter a kind of philhellenism that has transcended its initial limits as a partisan discourse on the modern Greeks to grow into a new kind of plural partisanship, engendering sympathies for all the Balkan nations, as nations, with the proviso that they must still fall within the realm of Christianity53. Combined with the notion of an historical symmetry

51 An important role in this played Stanley (A. P.)'s, Lectures on the History of the Eastern Church, London, 1861. See also Church (R. W), On Some Influences of Christianity upon National Character: Three Lectures Delivered in St. Paul's Cathedral, February 4 th, 11th and 18th, 1873, London, 1873. Church dedicated one lecture to each of three "races", which he categorized according to dogma. The first, dedicated to "The Character of the European Races belonging to the Eastern Church " was taken up entirely by the Greeks. The other two were " the Latin " and " the Teutonic " races.

52 See Freeman (E. A.), " Finlay on the Byzantine Empire ", North British Review, 22, February 1855, pp. 343-375, "The Eastern Church ", Edinburgh Review, 107, April 1858, pp. 322-357 and The Eastern Question in its Historical Bearings : An Address Delivered in Manchester, November 15, 1876, Manchester, 1876.

53 Freeman's perspective on Europe, the Slav nations and the Greeks, can be compared with that of Cyprien Robert, Prof. of Slav Literature in the Collège de France, who wrote about a " peuple ", a " race " and a "monde Gréco-Slave "; See, in particular, Robert (Cyprien), Les Slaves De Turquie : Serbes, Monténégrins, Bosniaques, Albanais et Bulgares, Leurs Ressources, Leurs Tendances et Leurs Progrès Politiques, Paris 1844, pp. 1-97. Unlike Freeman, who insisted on institutional symmetries between the medieval West and Byzantium, Robert emphasized the antithetical processes of historico-political evolution amongst the " western nations $n$ and the "Slavs ". Yet, both believed that there were two distinct, but related facets of the European " spirit " (an " eastern " and a " western " one), which were, ultimately, classically derived ; and they both used notions of ancient and modern " Greekness " as mediators between the Slavs and Europe. 
between Western and Eastern Europe, this perspective, which was by no means Freeman's alone, sharpened anew the conceptual boundaries between "Europe" and the Ottoman Empire in late nineteenth century Britain, and enhanced images of the Ottoman Christians as European captives of a foreign and barbarous power.

And this brings us to the last part of this article, i.e. to the assessment of the relationship of earlier philhellenic and Turkophile perspectives on the Eastern Question with the development of late nineteenth and early twentieth century British Balkanology.

\section{THE GREEKS AND THE BALKAN FAMILY OF NATIONS, 1856-1910}

\section{Slavophiles and Philhellenes : A generic connection ?}

The mid-185os was an important turning point in the evolution of British discourse on the Eastern Question. Apart from the emergence of a generation of "new" philhellenes, the period of the Crimean War signaled also the emergence of British interest in the "national" fate of the South Slavs. Indicatively, it was in 1853 that a new, enlarged edition of the English translation of Leopold von Ranke's History of Serbia appeared. To this, the publisher had added not only a translation of Ranke's writings on Bosnia, but also a compilation essay on "The Slave Provinces of Turkey ", taken mainly, but not exclusively, from Cyprien Robert's Les Slaves de Turquie (Paris, 1844)54. The perspective on the Eastern Question represented by this edition, a perspective within which support for the "patriotic struggles " of various Balkan nations was placed in the center of a much more diffuse, but ideologically powerful concern for the " oppressed Christian nationalities " of the Ottoman Empire, would acquire its full political and ideological potential only during the Bosnian and Bulgarian crisis of the mid-1870 55 . Its main conceptual parameters, however, had already emerged, amongst a narrower circle of Slavophiles, at the time of the Crimean War.

Did these new sympathies introduce significant discontinuities in the Eastern Question debate in Britain ? To answer this question we should first

54 Ranke (Leopold von), The History of Servia and the Servian Revolution; With a Sketch of the Insurrection in Bosnia, translated from the German by Mrs. Alexander Kerr, London, 1853 . The first edition of the translation of Ranke's History of Serbia (1829) had appeared in 1847, while the part on Bosnia was a translation of Ranke's Die Letzten Unruhen in Bosnien (1820-1832).

55 See Shannon (R. T.), Gladstone and the Bulgarian Agitation 1876, London, 1963, passim, Goldsworthy (Vesna), op.cit., pp. 22-41. 
inquire whether the British travelers, journalists and scholars who wrote in favor of the Ottoman Slavs in the late nineteenth and early twentieth century shared the general perspective of the "new" philhellenes, as I have described it above ; secondly, we should inquire how was their discourse diversified in correlation to the particular nation that each of them supported ; and, finally, we should look for continuities and discontinuities between earlier and later partisanships, both on the level of stereotypes that each discourse reiterated, and on the deeper level of the values they alluded to.

At first sight, the evidence concerning the congruence of philhellenic and Slavophile perspectives in the 1860 s, 1870 s and 188 os appears overwhelming. When we study "philhellenism" and "Slavophilia" in these decades we frequently encounter the same people, as for example in the cases of the philhellenes W.E. Gladstone and E. A. Freeman, who were also central figures in the "Bulgarian atrocities" agitation of 1876 . Moreover, there is very little evidence in the writings of the Slavophiles of this period either that Greece was excluded from their visions of "Balkan liberation", or that the antagonism between "Greeks" and "Slavs" was anything more than a secondary aspect of the problem in their eyes. For example, in the series of pamphlets published by the Eastern Question Association in 1877-1878, under the general title " Papers on the Eastern Question ", a paper on Turkish Rule on Crete was included ${ }^{56}$, and the Greeks were often mentioned elsewhere, favorably and on an equal footing with the other nations of the peninsula57.

In addition, not only in political propaganda, but also in the writings of influential travelers of the second half of the nineteenth century we find ample evidence of the central role they attributed to Orthodoxy as determining the identity of the Balkan region, a perspective which is very familiar from the writings of the "new" philhellenes. For example, such is the perspective of Henry Tozer in his Researches in the Highlands of Turkey ${ }^{8}$ and of Georgina Mackenzie and A. P. Irby in their Travels in the Slavonic Provinces of Turkey in Europe (first published in 1867, but re-issued, with additions and with a Preface by W. E. Gladstone in the midst of the Bosnian / Bulgarian crisis, in 1877) 59 .

Precisely because this common philhellenic / Slavophile world-view was above all else Turkophobe and anti-Islamic, its adherents tended to group together all the Ottoman/Balkan nationalities as "Eastern Christian", pushing to

56 Skinner (J. H.), " Turkish Rule in Crete ", Papers on the Eastern Question, (9), 1877.

57 Campbell (G.), " The Races, Religions and Institutions of Turkey and the Neighboring Countries ", Papers on the Eastern Question, (4), 1877, pp. 21-22 ; Denton (William), " Fallacies of the Eastern Question ", Papers on the Eastern Question, (8), 1877, p. 4.

58 Tozer (Henry Fanshawe), Researches in the Highlands of Turkey, 2 vols, London, 1869.

59 Mackenzie (G. Muir) / Irby (A.P.), Travels in the Slavonic Provinces of Turkey in Europe, 2 vols, London, 1877 . 
the background, if they could not ignore, concerns about a possible outbreak of nationalist conflict amongst them ${ }^{60}$. This, however, did not preclude all discussion of nationalist tensions between "Slavs" and "Greeks", nor did it impede the formulation of particular stereotypes of various Slav peoples and of their relationship to each other in such literature.

For example, in his brief discussion of the political aspects of the Eastern Question placed within a book concentrating on the description of monasteries and churches and on the comparative study of folklore ${ }^{61}$, Henry Tozer predicted that " the Greek and the Slavonic races " would ultimately divide the peninsula between them. There was no allusion to a possible future conflict amongst the Slavs themselves, and Serbs and Bulgarians were presented as natural allies, as members of the same Slavic family.

And yet, Tozer's perception of the national character of the two peoples distinctly placed the two " nationalities " in different categories. The Bulgarians he saw as a " naturally agricultural " people, as a passive community, who, in his view, would ideally form the subordinate part in a union with the " commercial "Greeks ${ }^{62}$. "The Serbs, the Bosniacs, the Montenegrins and the other Slavonic nations " (sic), on the other hand, were presented as a people of an " unyielding temperament and strong national feeling ", whose national character was ultimately irreconcilable with that of the " quick, subtle, impulsive, over-reaching, and "too clever by half" "Greeks ${ }^{6}$. Thus, in terms of their prospects of autonomous political existence, Greeks and "Serbs" were put on an equal footing, while Bulgarian autonomy was precluded.

Mackenzie's and Irby's images of the Balkans, although equally Churchframed, were colored by much more intense pro-Serb feeling. Their book clearly reveals the generic relationship that existed between philhellenic discourse and pro-Serb/Montenegrin sympathies in Britain ${ }^{64}$. For example, in the stereotypical images of the Serbs (and especially of the Montenegrins) painted by the authors, we find that, apart from being described as brave and patriotic, the Montenegrins are also frequently compared with the Scottish highlanders, something very familiar from the accounts of the "mountaineer " Greeks

60 This perspective was frequently retained long after nationalist antagonism in Macedonia had become too pervasive to ignore. For example, Buxton (Noel), Europe and the Turks, London, 1907, with Freeman (Edward)'s much earlier Ottoman Power in Europe; Its Nature, Its Growth and Its Decline, London, 1877.

61 Tozer (Henry Fanshawe), op. cit., 1, pp. 389-397.

62 Ibid., 1, p. 395. He believed, however, that this would not ultimately happen, because the other Slavs encouraged their disaffection with the Greeks.

63 Ibid., 1. p. 396.

64 See Mackenzie (G. Muir) / Irby (A.P.), op.cit., mainly the chapters on Serbia, pp. 14-33, 280-327. 
since the time of Byron. Also, the younger generation is represented as seeking enlightenment from Europe, another very common philhellenic theme ${ }^{65}$. Finally, when the violent military habits of the Montenegrins are discussed, such accounts are frequently tempered with a sense of humor and with allusions to their " child-like " character, something very familiar from some midnineteenth century accounts on Greece ${ }^{66}$.

Nevertheless, this book also exemplifies the limits of the relationship between philhellenism and Slavophilia during this period. While Mackenzie and Irby did not express hostility towards the modern Greeks, they often denounced the higher hierarchy of the Orthodox Church and the "Phanariots" for their historical and contemporary efforts to suppress the language and national rituals of the Slav populations ${ }^{67}$.

This indicates the extent to which - and partly the reason why - the supporters of Greek and Slav nationalism in Britain had already started to grow apart. Indeed, the emphasis that the supporters of the "Eastern Christians" of this period, philhellene and Slavophile alike, placed on Byzantine, medieval and Church history, combined with the gradual consolidation of conceptions of nationhood around language and race, would gradually make untenable the most extreme claims of Greek nationalism in the eyes of Slavophiles (cum philhellenes) of Gladstone's and Freeman's sort. Consequently, their philhellenism sometimes appears as a preparatory stage, through which their wider Balkan sympathies evolved ${ }^{68}$.

Moreover, British philhellenism in its narrower, merely pro-Greek sense enhanced its links with academia during the last decades of the century. This development was put into motion by the creation of the Society for the Promotion of Hellenic Studies in 1879 . The Society was created by the combined efforts of a group of British classicists and the active Greek Minister in London, Joannis Gennadios, while it was modeled upon the contemporary French

65 Ibid., 2, pp. 213-279.

66 Ibid., 2, p. 235 : "Kertso was a Montenegrin of the old school ; simple, kindly even child-like in all circumstances but the heat of battle, and absolutely unconscious that a any idea of horror can be associated with cutting off the head of a Turk ". This ambivalence between the terrifying and the picturesque is strongly reminiscent, for example, of About (Edmond)'s, Le Roi des Montagnes, first published in Paris in 1857 and translated in English in 1861.

67 Ibid., 1, p. 16.

68 And yet, the kind of critique that the Slavophiles of this period expressed "against the Greeks" presupposed an elevation of de-centralized Church hierarchies, on the one hand, and of religious irredentism, on the other, to national symbols. The idea that autonomous Church institutions could be "badges" of particular national identities was related, but was not derivative from the more traditional idea that Christianity (as opposed to Islam) had historically instilled moral cohesion both amongst and between nations. In Britain, such particularly Anglican notions about the national importance of Church institutions had been applied first to the Greek national / historical context and then passed over to the Slavs by philhellene scholars like A.P. Stanley and E. Freeman. 
Association pour l'Encouragement des Etudes Grecques. Its orientation was from the start primarily archaeological, and its main contribution in future years was the publication of the Journal of Hellenic Studies (since 1880). The Society was also closely involved with the establishment, and partly with the financing of the British School of Athens $(1886)^{69}$.

These developments led to a particular institutionalization of certain strands of philhellenic discourse in Britain, and, given the preponderant number of archaeologists and classicists in these circles, they also encouraged a reliance of British perceptions of Greek modernity upon British Hellenism ${ }^{70}$. This created a very different context for the cultivation of sympathies for the modern Greeks, different both from the context within which earlier philhellenic strands had developed, and from that of contemporary Slav sympathies. While the "friends" of the Serbs or the Bulgarians still addressed their audience through an openly politicized or journalistic discourse, being a "philhellene" gradually became an ostensibly more distanced and academic issue, that did not preclude, but could discourage, open partisanship ${ }^{71}$.

Indeed, much of the tendency of contemporary scholarship to subsume "philhellenism" under "Hellenism" seems to derive from the perusal of accounts of modern Greece that were written within this context. For, it is amongst philhellenes of this sort that we frequently find the construction of images of modern Greece as a living museum, within which "the scholar", either archaeologically or ethnologically inclined, could distance contemporary political controversy in virtue of his own disciplined and "expert" knowledge

69 See Macmillan (George A.), An Outline of the History of the Society for the Promotion of Hellenic Studies $1879 \cdot 1904$, London, 1904. For the role of the Society in the context of British Hellenism, see Stray (Christopher), op. cit., pp. 137-139.

70 While the avowed aim of the Society, as declared in its "Rules n, was " to advance the study of the Greek language, literature and art, and to illustrate the history of the Greek race in the ancient, Byzantine and Neo-Hellenic periods ", the inaugural address of Charles Newton, Chair of the society's Committee, made it quite clear that the motive for the study of Greek literature and Greek history after antiquity was to " trace out the connection " with the ancient Greeks. Newton also expresses the intention of the Society to keep itself aloof from the political aspects of the Eastem Question and to provide " a neutral ground, on which Englishmen and Greeks may in the interest of leaming co-operate without coming into collision on account of political differences". See Newton (C. T.), "Hellenic Studies : an Introductory Address ", Journal of Hellenic Studies, 1, p. 1-6.

71 It was not until the creation of the Anglo-Hellenic League in 1913, that organized philhellenism in Britain re-acquired an openly partisan character, at this time identified with Venizelism. On tensions between academia and politics in this context see Clogg (Richard), Politics and the Academy : Amold Toynbee and the Koraes Chair, London, 1986. 
of "the ancient land and its people"72. Thus, more frequently than not from then onwards, to approach Greece as a "Hellenist" became a means of extracting the country from its Balkan context, while, at the same time, distancing oneself from the need to take an open stand on controversial political issues.

The significant ideological potential of this ostensibly "apolitical" position, as a means of cultivating exclusive British support for Greek nationalist aspirations at the expense of "un-classical" neighbors, were hardly lost, either amongst the strategists of Greek foreign policy or amongst their Bulgarian and Serbian competitors at the turn of the century ${ }^{73}$.

\section{The Bulgarians and the Macedonians : an un-Greek kind of nationalism ?}

The above considerations qualify, but do not cancel the fundamental convergence of philhellenic and pro-Slav perspectives during this period - at least of tempered Greek sympathies and Slavophile perspectives of a pro-Serbian hue. The growth of British sympathies for the Bulgarians, on the other hand, is a more complex phenomenon that merits separate analysis.

Being viewed for most of the second half of the nineteenth century as a "passive" nationality, the Bulgarians attracted various kinds of sympathy from various quarters. Thus, a distinction should be made in their case between those "sympathizers" who fully embraced the Bulgarian nationalist movement (or, later, its Macedonian offspring) and those who sympathized with them precisely because they were considered passive, and therefore the living antithesis of their actively nationalist neighbors.

These considerations have of course a lot to do with historical context and timing. For example, in the 1850 s and 1860 s, we find an ardent sympathizer of the Bulgarians in the British linguist and oriental secretary at Istanbul Percy

72 A good example is Mahaffy (J. H.), Rambles and Studies in Greece, London, 1876. The process by which the "Hellenist ", as a non-political expert on the country and the people, could avoid, by a detour, local political and historical controversy is exemplified in Mahaffy's discussion of competing Greek and Turkish arguments concerning the causes of the depopulation of the Morea (ibid, pp. 9-11). While citing the mutual blame that the two peoples piled upon each other on the issue, the scholar presented himself as keeping a discrete silence, in virtue of being aware, on the authority of Strabo, that the peninsula had gone to ruin long before it had been ruled by either Turks or Greeks. For an example of the " ethnographic " version of such " Hellenic " literature see Rodd (Rennell), The Customs and Lore of Modern Greece, London, 1892. This work, much more charming than Mahaffy's book and very explicitly geared towards modernity, is still very much determined by the " Hellenic Studies " paradigm : Greek folklore is understood in terms of a survival of ancient Greek lore, while modern politics are totally absent.

73 Mahaffy (J. H.), op.cit., pp. v-xix, where the Irish classicist declares that although he is " no enthusiast about the modern, any more than about the ancient Greeks ", they are much to be preferred to the Bulgarians and the "turbulent and mischievous Serbians ". His philhellenic arguments are of a redundant nature : the Greeks are simply " vastly more intelligent, more peaceable, more civilized " than their neighbors (pp. vi-vii). And yet, Macaffy argued that parliamentary government did not suit Greece, which should be ruled, like Ireland, by a Governor-General (p. xi). 
Ellen Smythe, eighth Viscount Strangford, who contributed many articles on the Eastern Question to the British press at the time, especially to the Pall Mall Gazette 74 . Strangford was against Greek and Serb nationalist aspirations, while his sympathy for the Bulgarians was placed within the context of a distinctly Turkophile perspective quite similar to that of Henry Layard, which I have described above. Thus, his insistence that " the vast and homogeneous majority of the Christian population in European Turkey consists of Bulgarians" and his efforts to distinguish the national feelings of the Bulgarians from those of the other Slavs, cannot be separated from his belief that the Bulgarians had not yet " risen to the conception of liberty at all, and that, consequently, they were far from being " ripe for rebellion 75 .

Alternatively, on the other side of the Turkophile/Turkophobe divide, during the crisis of $1875-78$, which ultimately led to the Treaty of Berlin and to the creation of an autonomous Bulgaria, the very image of the passivity of the " industrious ", " calm " and " self-sufficient " Bulgarian peasants ${ }^{76}$ rendered them ideal "victims" in anti-Ottoman propaganda such as W.E Gladstone's famous Bulgarian Horrors and the Question of the East (London 1876). And yet, while these years represent an inaugural moment in respect to the formation of the Bulgarian body-politic, we find surprisingly little discussion in the writings of British "Bulgarophile" pamphleteers of the time about the political prospects of a future Bulgarian state.

Interestingly, however, whenever we do find such discussion, we may also discern continuities with earlier British debates on Greek politics. For example, in his Scheme for the Future Government of Bulgaria, published in 1878, Sir Edmund Hornby, "late H.B.M.'s Chief Judge for China and Japan, and formerly Judge of H.B.M.'s Supreme Consular Court for Turkey ", envisioned placing future Bulgaria under a " cosmopolitan bureaucracy $" 77$. The aim of such

74 Collected after his death by his wife Smythe (Emily Anne) in Writings of Viscount, Strangford, 2 vols, 1869.

75 Ibid., p. 17 (from " Chaos ", pp. 1-68, written in 1863).

76 This stereotypical image of the Bulgarians was repeatedly reiterated in relevant literature throughout the last thirty years of the nineteenth century. Apart from examples mentioned in the text, see also Barkley (H. C.), Bulgaria Before the War, London 1877, pp. x-xii ; Minchin (James George Cotton), The Growth of Freedom in the Balkan Peninsula. Notes of a Traveler in Montenegro, Bosnia, Servia, Bulgaria and Greece, with Historical and Descriptive Sketches of the People, London 1886, pp. 17, 340-345. Minchin, who served for a time as a Serbian Consul-General in London, considered the "peasant "Bulgarian as the very antithesis of the " gentleman " Montenegrin (ibid, p. 17).

77 Homby (Edmund), A Scheme for the Future Government of Bulgaria, London, 1878 , p. 11. In the context of this bureaucracy each major European nation would be entrusted with the task of government most proper to its own "talents". Thus, the English would supervise the administration of justice (as well as providing the Governor-General), the military and education would be in the hands of Germans, finances would be administrated by the French, transport by the Austrians, commerce and trade by the Italians and foreign policy by the Russians (see ibid., p.12). 
a system, according to Hornby, was to preclude Bulgarian assimilation into any wider South-Slav political formation, while helping the Bulgarians to develop their own " national " political culture, out of the democratic and communitarian traditions that the nation had preserved in its local communities $^{78}$. Like many commentators on Greece before him, Hornby "discovered" amongst the Bulgarians a rudimentary propensity to freedom that could "bloom " into a system of real self-government, provided that the Bulgarians would be guided, " in their infancy ", by benevolent Europeans 79 .

The political life of the newly created Bulgarian state, before and after the unification of Bulgaria with Eastern Roumelia in 1885 , did not receive a univocally bad press in Britain during the last decades of the nineteenth century, even if satirical representations of Balkan politics started to appear ${ }^{80}$. Positive and peaceful images of the "Bulgarian" national character, however, started to change dramatically around the turn of the century, as the Macedonian movement reached its height. For example, in the writings of Edith Duhram (and especially in her Burden of the Balkans, published in 1905) the "Bulgarian " nationalists of Macedonia were presented in the darkest possible colors, as terrorists ready to sacrifice their own people to serve sinister religious and political ends ${ }^{81}$. As for the Macedonians at large, they were still depicted as passive and child-like peasant victims, but their passivity was now colored by connotations of inferior intelligence that rendered it a much more negative characteristic than it had ever been in earlier accounts.

And yet, the Slavs of Macedonia would find a very ardent advocate during the same years in the well-known journalist $H$. N. Brailsford, who, after working with Durham in Monastir for the British Relief Fund, wrote the most interesting English account on Macedonia of the first decade of the twentieth century ${ }^{82}$. While Brailsford's perspective was very strongly anti-Ottoman, it was by no means primarily religious, or historically oriented. Instead it was focused on the village life and the oppression of the Macedonian peasantry (whom he considered to be ethnically Bulgarian in their preponderant majority).

Brailsford often sounds critical of Balkan nationalism as a whole. « It matters very little ", he writes already in his preface, "whether a village which was originally neither Greek nor Bulgarian nor Servian is bribed or persuaded

\section{Homby (Fdmund), op. cit., pp. 6-7.}

79 This belief that the Balkan nations had, ultimately, both the potential and the right to self-government distanced discourse on Balkan politics from colonial discourse (even if the authors of such schemes came frequently from colonial contexts).

Bo Goldsworthy (Vesna), op.cit., pp. 113-117. For a very positive account of Bulgarian political life and, also, Bulgarian wartime morality see Minchin (James George Cotton), op. cit., pp. 304-331.

81 Duhram (Edith), The Burden of the Balkans, London, 1905. pp. 209-226.

82 Brailsford (H. N.), Macedonia. Its Races and Their Future, London, 1906. 
or terrorized into joining one of these national parties. But it matters profoundly that it should be freed from the oppression of its landlord, its taxfarmer, and the local brigand chief $" 8_{3}$.

More attentive reading, however, shows that Brailsford was not a critic of all kinds of national struggle, but was genuinely impressed by the Macedonian revolutionaries ${ }^{84}$. Not only he embraced their aims, but also what he saw as their positive " patriotic " virtues : the village-level appeal of their movement ; its " local " Macedonian character ; and their " democratic " organization. These characteristics positively distinguished it, in his view, from the Serbian and Greek movements in Macedonia, both of which he considered as " the creation of the Greek and the Serbian governments " 85 . Especially Greek nationalism in Macedonia presented for him the very antithesis of the Macedonian patriotic struggle. He writes :

The Slavs of European Turkey, have ever yet no highly-developed consciousness of race, and what little they possess is of recent growth. Their passion is not for their race but for their country. They are a people of the soil fixed in their immemorial villages, with a limited range of sentiments which play piously around their mountains, their rivers and their ancient churches. A nation of peasants which starts with these conservative qualities will readily develop a genuine local patriotism. And this indeed has happened despite adverse circumstances ${ }^{86}$.

\section{On the contrary :}

The Greeks are townsmen, reared on abstractions, who care nothing for the soil of Macedonia, and very much indeed for "Hellenism". They are, moreover, an aristocracy of talent, whose chief interest is the Church they govern, and they have ingrained an Imperial tradition which knows nothing of local patriotism ${ }^{87}$.

Even if Brailsford's conception of the patriotism of the Macedonian peasants was not unrelated to a discourse on the "village republics of the Slavs" that we find mentioned in various accounts from the 1870 os onwards, there is no indication in his book that his sympathy for the Macedonian movement stemmed from any conscious re-deployment of arguments that were used in the middle of the nineteenth century either by philhellenes or Turkophiles. On the contrary, while his main argument was against the "Turks", his particular invective was reserved for "Hellenists" (the term including both the Greek nationalists themselves, and their British and European supporters),

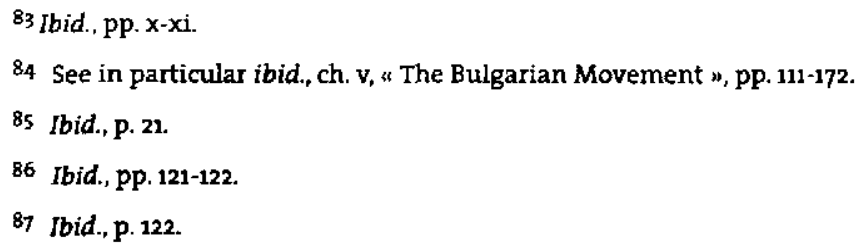


who promoted Greek nationalism as an ideology of a superior kind than that of their Slav competitors in Macedonia. If Brailsford's argument enlisted "local virtue" against "cosmopolitan talent", the defenders of Greek rights in Macedonia in the first decade of the century were promoting the opposite argument, emphasizing the " higher education " of the Greeks, as well as the voluntarist and "idealist" nature of their own national idea, as opposed to the " narrow" and " instinctive " national ideology of their " surly " neighbors, that was " determined by blood " 88 .

And yet, the terms in which Brailsford built up his two alternative versions of national struggle in the previous extracts, juxtaposing " townsmen" to " villagers ", " race " to " country ", " love for the soil " to " Great Ideas ", an " aristocracy of talent " to a people of " peasants fighting for a minimum of liberty "(sic), are strongly reminiscent, when all differences of historical circumstance are taken into account, of the kind of advocacy that early philhellenes (like George Finlay), and early Turkophiles (like David Urquhart), had extended to the peasant populations of "Greece" and "Turkey", as opposed to the political and social elites of the respective central states.

It seems then, that irrespective of different theories regarding the original source from which the "local patriotism" of the Balkan peasantry was allegedly derived, and irrespective of which "nationality" each of the British partisans "adopted", the trope of a fundamental antithesis between the kind of patriotism that was engendered in the Balkan villages and the kind of "national virtue" alluded to by educated Balkan "townsmen" (Greeks or otherwise) and their friends in the West ("Hellenists" or otherwise) remained intact.

Such continuities suggest that, while in the first decade of the twentieth century the Greeks on the one hand, and the Bulgarians of Macedonia on the other, occupied the antithetical poles of this binary opposition in British eyes, it may be wrong to treat this antithesis as an unproblematic reflection of the actual ideological content of early twentieth-century Greek and Bulgarian and/or Macedonian nationalism. Rather, what the resilience of this trope within nineteenth-century British discourse on the Eastern Question seems to indicate is a deeply-seated British ambivalence concerning the notion of Ottoman/Balkan "nationality", an ambivalence cutting across sympathies for Greeks, Turks, and Slavs, and influencing the "internal"

88 See Abbott (G.E.), ed., Greece in Evolution, London, 1909, a volume of "Studies Prepared Under the Auspices of the French League For the Defence of the Rights of Hellenism n, translated from the French and prefaced by Dilke (Charles W.). See in particular Dilke's "Preface "; Paillarès (Michael), " Hellenism in Macedonia ", in ibid., pp. 133-162 and Berl (Alfxed), "Modern Greece : What She Represents in Eastern Europe ", in ibid., pp. 235-260. Quotes from the last essay, ibid., pp. 244-245. 
as well as the "external" moral hierarchies of the Balkan nations, as these were perceived by British sympathizers ${ }^{8}$.

We may also argue, that what was most important in the construction of such hierarchies was not a genuine question about the origin or the "historical rights" of each Balkan nation (since a "nationality" in its entirety could be made to represent the values that, under other circumstances, would be attributed only to a class within a nation). Rather, what was central in such discursive distributions of legitimacy was the partisan's understanding of the relationship between two kinds of virtue : particular, exclusive kind of virtue associated with "patriotism" on the one hand, and the wider "universalistic" kind of virtue, associated with belonging to, representing and fighting for Western/European civilization on the other.

As this double-faced moral imperative was projected upon a region whose exact positioning in respect to the West remained in flux, the conceptual ambiguities that it entailed produced an ongoing tension between the kinds of relationships that British partisans envisioned between "local peoples" (sedentary, but "pure"), their "corrupt" (but mobile) socio-political elites, and an all-powerful and sympathetic "Europe", which, not only represented the idealized alter ego of their own national identity, but was also considered to have ultimate authority over each Balkan nation's transition to modernity.

Attempting, in conclusion, a projection of my own beyond the chronological and topical limits of the present essay, I would suggest that recognizing the resilient character of such tensions, that survived the profound nineteenth-century political transformations in the Ottoman/Balkan area, may illuminate the terms of a yet unfinished discussion on political autonomy and international solidarity, that lies at the very center of actual and symbolic interaction between peoples in the "periphery" and their "Western" friends.

89 That is to say that this ambivalence determined both how the social structure within each national body was judged, and how the national legitimacy of different peoples was "graded". 